\title{
Epidermal growth factor (EGF) facilitates depilation of the Angora rabbit
}

\author{
G.P.M. MOORE, R.-G. THÉBAULT ${ }^{(*)}$, J. ROUGEO'T ${ }^{(*)}$ and P. VAN DOOREN \\ with technical assistance of $\mathrm{M}$. BONNET
}

C.S.I.R.O., Division of Animal Production, P.O. Box 239, Blacktown, N.S.W., 2148, Australia.

* INRA, Centre de Recherches de Poitou-Charentes, domaine expérimental du Magneraud, URLAF, B.P. 52, F 17700 Surgères.

** I.T.A.V.I., 12, rue du Rocher, F 75008, Paris.

\begin{abstract}
Summary
The depilatory effects of epidermal growth factor (EGF) were investigated in the Angora rabbit. The time taken to remove the angora wool by plucking was measured in 30 animals (including 6 controls) 5-8 days after subcutaneous injection of EGF (dose range $25-200 \mu \mathrm{g} / \mathrm{kg}$ body weight). The rate at which the fibres could be harvested was increased after EGF treatment and was dependent on the amount administered. At dose levels of $100-200 \mu \mathrm{g} / \mathrm{kg}$ body weight the duration of the depilation procedure was halved in comparison with controls.
\end{abstract}

Key words : Angora rabbit, EGF, plucking, angora wool, rabbit.

\section{Introduction}

Epidermal growth factor (EGF) isolated from the mouse is a small polypeptide composed of 53 amino acids with three disulphide bridges (SAvage et al., 1973). A family of related molecules may exist in mammals as sequences with similar structures but varying degrees of homology in composition have been identified in man (GREGORY, 1975) and the rat (SIMPSON et al., 1985). A role for EGF in the growth and maintenance of the skin is indicated by the identification of EGF receptors in cell populations of the epidermis, dermis and hair follicles (GREen et al., 1983 ; HolleNBERG \& Cuatrecasas, 1973 ; NANNEY et al., 1984). Injections of EGF into mice after birth resulted in precocious eyelid opening and an inhibition of hair growth (LEvIMontalcini \& COHEN, 1960 ; MOORE et al., 1981 a). An accompanying increase in thickness of the epidermis (COHEN \& ElliotT, 1963) was shown to be due to a developmental delay in its maturation (MOoRE et al., 1983). Treatment of sheep with EGF induced a marked erythema (PANARETro et al., 1982) associated with a striking increase in skin blood flow (PANARETTO unpublished observations 1987), increases in mitotic activity (MI) of the basal epidermal cells and peripheral cells of the sebaceous glands and there was a decrease in the MI of the follicle bulb cells (Moore et al., 1985). The follicles underwent a brief phase of regression (Hollis et al., 1983) in which 
fibre output was reduced, leading to the development of a weakness in the fibres (MoOre et al., 1981 b, $1982 \mathrm{a}, \mathrm{b}$ ). The application of EGF as a wool harvesting agent for sheep is currently being investigated using a protein derived from bacteria transformed with a synthetic EGF gene (Allen et al., 1987). The present report describes a preliminary study of the application of EGF for depilation of other domestic species which produce commercial fibres. The Angora rabbit produces a textile fibre of high quality, distinguished for its exceptional softness and lightness. In France, the hair is harvested at approximately 100 day intervals by plucking. We show that administration of EGF to Angora rabbits considerably increases the rate at which the pelage may be removed by this procedure.

\section{Materials and methods}

EGF was prepared from the salivary glands of adult male mice by the method of SAVAGE AND COHEN (1972). Briefly, acidified extracts were fractionated on a Biogel P 10 column and the EGF-containing fraction was chromatographed on a DEAE cellulose column. The major peak was concentrated, dialyzed and lyophilized and its identity was established by electrophoretic analysis on cellulose acetate gets. The EGF was dissolved in physiological saline and glycerol $(1: 1 \mathrm{v} / \mathrm{v})$ at a concentration of $0.2 \mathrm{mg} / \mathrm{ml}$ and stored before use at $5^{\circ} \mathrm{C}$.

Thirty adult female French Angora rabbits were housed individually in cages. Animals were assigned randomly to 5 groups : the first, control group, was injected with vehicle $(2 \mathrm{ml})$ and the remaining groups with nominal doses of $25,50,100$ and $200 \mu \mathrm{g} \mathrm{EGF/kg} \mathrm{body} \mathrm{weight} \mathrm{(table} \mathrm{1).} \mathrm{The} \mathrm{solution} \mathrm{was} \mathrm{injected} \mathrm{intramuscularly} \mathrm{in}$ volumes ranging from $0.4-4.6 \mathrm{ml}$. Each animal was treated with EGF at the time at which the angora wool was usually harvested after the previous depilation.

The angora wool was plucked from all animals $5-8$ days after injections with EGF or vehicle. The effectiveness of the treatments was measured by timing each of the three phases of the depilation procedure (table 1). The first phase began after the animal had been immobilised on a depilation table (Rougeot \& Thebaut.T, 1984) and consisted of removing soiled and felted wool from the neck, stomach and anus. During the second phase, the finest quality fibres were plucked from the flanks, back, rump, belly and throat followed by the shorter fibres from the upper regions of the limbs. The third phase consisted of removing the remaining hair with scissors from the tail, the head and the paws.

\section{Results}

EGF facilitated the removal of the angora wool in a dose dependent manner (table 1). The greatest effect was found during harvest of the main body wool (phase 2). In animals which received $100-200 \mu \mathrm{g} / \mathrm{kg}$ body weight EGF plucking was approximately 2-3 times faster than for controls. The time taken to recover felted hair and hair from the extremities (phases 1 and 3) was only moderately shorter. The total time taken to depilate rabbits at the two highest dose levels ranged from 11-17 minutes, which was approximately half that required from vehicle-treated controls. 
TABLE 1

The effect of EGF on the rate of removal of hair from Angora rabbits

\begin{tabular}{|c|c|c|c|c|c|c|c|c|}
\hline \multirow[t]{2}{*}{$\begin{array}{c}\text { Animal } \\
\mathrm{n}^{\circ} \\
N^{\circ} d e \\
\text { lanimal }\end{array}$} & \multirow[t]{2}{*}{$\begin{array}{l}\text { Pelage- } \\
\text { free wt } \\
\text { Poids vif } \\
\text { (sans pelage) } \\
\text { kg }\end{array}$} & \multirow[t]{2}{*}{$\begin{array}{c}\text { EGF } \\
\text { administered } \\
E G F \\
\text { administré } \\
\mu \mathrm{g}\end{array}$} & \multirow[t]{2}{*}{$\begin{array}{l}\text { EGF } \\
\text { dose } \\
\text { Dose } \\
d^{\prime} E G F \\
\mu \mathrm{g} / \mathrm{kg}\end{array}$} & \multicolumn{3}{|c|}{$\begin{array}{l}\text { Duration (min) of } \\
\text { depilation phases } \\
\text { Durée (en mn) des } \\
\text { différentes phases } \\
\text { de la dépilation }\end{array}$} & \multirow[t]{2}{*}{$\begin{array}{l}\text { Total } \\
\text { duration } \\
\text { Durée } \\
\text { totale } \\
\text { mn }\end{array}$} & \multirow{2}{*}{$\begin{array}{c}\text { Wt of } \\
\text { wool } \\
\text { Poids } \\
\text { du poil } \\
\text { récolté } \\
\mathbf{g}\end{array}$} \\
\hline & & & & 1 & 2 & 3 & & \\
\hline $\begin{array}{ll}4 & 222 \\
4 & 238 \\
4 & 258 \\
4 & 092 \\
4 & 102 \\
3 & 146\end{array}$ & $\begin{array}{l}3.75 \\
4.60 \\
3.99 \\
3.78 \\
3.98 \\
4.34\end{array}$ & $\begin{array}{l}0 \\
0 \\
0 \\
0 \\
0 \\
0\end{array}$ & $\begin{array}{l}0 \\
0 \\
0 \\
0 \\
0 \\
0\end{array}$ & $\begin{array}{l}2.5 \\
3.7 \\
4.3 \\
2.7 \\
3.8 \\
3.3\end{array}$ & $\begin{array}{l}18.0 \\
28.8 \\
22.3 \\
18.3 \\
25.2 \\
25.5\end{array}$ & $\begin{array}{l}5.5 \\
3.3 \\
4.0 \\
2.0 \\
5.0 \\
4.5\end{array}$ & $\begin{array}{l}26.0 \\
35.8 \\
30.6 \\
23.0 \\
34.0 \\
33.3\end{array}$ & $\begin{array}{l}219 \\
318 \\
284 \\
242 \\
338 \\
269\end{array}$ \\
\hline mean & 4.07 & 0 & 0 & 3.4 & 23.0 & 4.1 & 30.5 & 278.3 \\
\hline $\begin{array}{ll}4 & 250 \\
5 & 166 \\
4 & 108 \\
4 & 110 \\
4 & 124 \\
5 & 062\end{array}$ & $\begin{array}{l}4.10 \\
3.31 \\
3.66 \\
4.00 \\
4.40 \\
4.20\end{array}$ & $\begin{array}{r}102 \\
82 \\
92 \\
100 \\
110 \\
106\end{array}$ & $\begin{array}{l}24.9 \\
24.8 \\
25.1 \\
25.0 \\
25.0 \\
25.2\end{array}$ & $\begin{array}{l}1.8 \\
2.6 \\
2.9 \\
4.1 \\
2.1 \\
1.4\end{array}$ & $\begin{array}{l}23.8 \\
22.5 \\
15.7 \\
13.5 \\
23.5 \\
20.4\end{array}$ & $\begin{array}{l}4.1 \\
4.7 \\
2.8 \\
2.0 \\
3.5 \\
2.0\end{array}$ & $\begin{array}{l}29.7 \\
29.8 \\
21.4 \\
19.6 \\
29.1 \\
23.8\end{array}$ & $\begin{array}{l}221 \\
183^{2} \\
238 \\
294 \\
283 \\
310\end{array}$ \\
\hline mean & 3.94 & 98.7 & 25.0 & 2.5 & 19.9 & 3.2 & 25.6 & 254.8 \\
\hline $\begin{array}{ll}5 & 162 \\
4 & 240 \\
4 & 100 \\
4 & 262 \\
3 & 244 \\
4 & 126\end{array}$ & $\begin{array}{l}3.60 \\
3.61 \\
4.26 \\
4.61 \\
3.83 \\
4.56\end{array}$ & $\begin{array}{l}180 \\
180 \\
214 \\
230 \\
192 \\
228\end{array}$ & $\begin{array}{l}50.0 \\
49.9 \\
50.2 \\
49.9 \\
50.1 \\
50.0\end{array}$ & $\begin{array}{l}2.3 \\
3.5 \\
2.3 \\
2.8 \\
1.6 \\
2.2\end{array}$ & $\begin{array}{l}10.4 \\
18.2 \\
20.3 \\
15.0 \\
12.0 \\
13.5\end{array}$ & $\begin{array}{l}3.5 \\
5.8 \\
3.0 \\
2.2 \\
2.2 \\
2.5\end{array}$ & $\begin{array}{l}16.2 \\
27.5 \\
25.6 \\
20.0 \\
15.8 \\
18.2\end{array}$ & $\begin{array}{l}170^{2} \\
221 \\
223 \\
246 \\
225 \\
257\end{array}$ \\
\hline mean & 4.08 & 204.0 & 50.0 & 2.5 & 14.9 & 3.2 & 20.6 & 223.7 \\
\hline $\begin{array}{ll}4 & 234 \\
5 & 164 \\
4 & 112 \\
3 & 166 \\
4 & 260 \\
4 & 128\end{array}$ & $\begin{array}{l}3.98 \\
3.51 \\
4.32 \\
3.30 \\
3.90 \\
4.37\end{array}$ & $\begin{array}{l}398 \\
352 \\
432 \\
330 \\
390 \\
438\end{array}$ & $\begin{array}{l}100 \\
100.3 \\
100 \\
100 \\
100 \\
100.2\end{array}$ & $\begin{array}{l}2.5 \\
1.3 \\
3.0 \\
1.6 \\
2.5 \\
1.5\end{array}$ & $\begin{array}{r}8.2 \\
9.8 \\
13.2 \\
11.3 \\
12.5 \\
9.7\end{array}$ & $\begin{array}{l}3.4 \\
2.8 \\
6.0 \\
2.7 \\
2.0 \\
2.8\end{array}$ & $\begin{array}{l}14.1 \\
13.9 \\
22.2 \\
15.6 \\
17.0 \\
14.0\end{array}$ & $\begin{array}{l}241 \\
197^{2} \\
261 \\
179^{2} \\
237 \\
237\end{array}$ \\
\hline mean & 3.90 & 390 & 100.0 & 2.1 & 10.8 & 3.3 & 16.1 & 225.3 \\
\hline $\begin{array}{ll}5 & 038 \\
4 & 232 \\
5 & 156 \\
3 & 236 \\
4 & 266 \\
4 & 270\end{array}$ & $\begin{array}{l}3.57 \\
3.66 \\
3.66 \\
4.55 \\
4.43 \\
4.01\end{array}$ & $\begin{array}{l}720 \\
732 \\
732 \\
910 \\
886 \\
802\end{array}$ & $\begin{array}{l}201.7 \\
200.0 \\
200.0 \\
200.0 \\
200.0 \\
200.0\end{array}$ & $\begin{array}{l}2.7 \\
1.5 \\
0.8 \\
2.3 \\
1.9 \\
1.3\end{array}$ & $\begin{array}{r}10.2 \\
8.0 \\
8.5 \\
8.5 \\
6.3 \\
8.3\end{array}$ & $\begin{array}{l}3.0 \\
2.5 \\
2.9 \\
2.0 \\
2.2 \\
2.6\end{array}$ & $\begin{array}{l}15.9 \\
12.0 \\
12.2 \\
12.8 \\
10.4 \\
12.2\end{array}$ & $\begin{array}{l}251 \\
238 \\
155 \\
210 \\
264 \\
255\end{array}$ \\
\hline mean & 3.98 & 797 & 200.3 & 1.8 & 8.3 & 2.5 & 12.6 & 228.8 \\
\hline
\end{tabular}

1. phase 1 : soiled, felted wool (belly, neck, anus). épilage du poil sali, feutré (bas-ventre, nuque, anus)

phase 2 : main body wool. épilage du corps.

phase 3 : wool from extremities (head, tail, lower limbs). toilettage (ciseaux), tête, queue, pattes.

2. Third harvest from animals at 8 months of age.

Troisième récole de poil, pratiquée à l'âge de 8 mois. 
Regrowth of the pelage was rapid and the tips of new hair fibres were visible at the skin surface after 14 days. The mean weights of the harvested pelage in treated rabbits was less than that of the control animals. This was due in part to the presence of younger animals in the former groups which had not reached their full production potential (table 1).

\section{Discussion}

The composition, structure and growth rate of the hair fibres of the Angora rabbit are similar to those of other rabbits. The Angora mutation however has resulted in a prolongation of the phase of follicular activity (anagen) so that whilst the duration of anagen in the New Zealand white rabbit, for example, is approximately 5 weeks, Angora rabbit hair grows for 3 months or more (Thebault \& Rougeot, 1983). The Angora pelage is usually harvested at intervals of 100 days although only $10-30 \%$ of the follicles may be at rest (telogen). Delays in harvesting increase the likelihood of felting as telogen follicles re-enter the growth phase and shed fibres grown in the previous cycle.

The most common methods of removal include shearing or plucking. The latter procedure requires considerable skill but has the advantage of mechanically stimulating the follicles which become synchronized over the whole body during the subsequent growth phase. Shearing is more rapid but results in a « woolly », less well structured pelage due to the presence of shorter fibres in the new coat which were shed from resting follicles still active at the time of shearing.

Previous attempts to facilitate the plucking procedure have included the use of cyclophosphamide (Rougeot \& Thebault, 1970). Cyclophosphamide was found to be toxic when delivered subcutaneously. A dose of $90 \mathrm{mg} / \mathrm{kg}$ which was required to produce a response in every animal, was fatal for two of the six treated rabbits. The more successful mode of administration was by oral way. Rabbits treated in a dose range of $60-140 \mathrm{mg} / \mathrm{kg}$ body weight all developed weakened fibres. At higher levels $(200-300 \mathrm{mg} / \mathrm{kg}$ body weight) most animals died.

The present experiments have demonstrated that EGF was a more potent harvesting agent than cyclophosphamide without the accompanying toxicity. Previous studies suggest that the mechanisms of action of both compounds in the skin were similar, in causing inhibition of mitoses within the cell population of the follicle bulbs (ROUGEOT \& Thebault, 1970, Moore et al., 1985). Following treatment the follicles regressed and the fibres were shed or developed weakened zones.

The more general application of EGF for fibre harvesting in rabbits is dependent on the outcome of future studies. It will be important to know how fibre production is affected by repeated treatments and whether there are any effects on reproductive functions and on foetal growth. EGF has been found to affect oestrus and ovulation rate in cycling ewes (SHAw et al., 1985 ; RADFORD et al., 1987) and the production of spermatozoa in rams (MATTNER et al., 1985). We have already reported that EGF treatment of ewes at different stages of pregnancy did not appear to affect foetal development or the delivery of normal lambs at parturition (MoorE et al., 1984).

Reçu en juin 1987.

Accepté en septembre 1987. 


\section{Résumé \\ Utilisation de "l'epidermal growth factor " pour faciliter la récolte du poil du Lapin Angora par dépilation} angora.

Les effets dépilatoires de l'«épidermal growth factor» (EGF) ont été étudiés chez le lapin

Le temps passé pour récolter le poil a été mesuré sur 30 animaux, 5 à 8 jours après une injection sous-cutanée d'EGF, à des doses variant de 25 à $200 \mu \mathrm{g} / \mathrm{kg}$ de poids vif, ou après injection sous-cutanée de solution seule (lot témoin).

La durée de la récolte a été très sensiblement diminuée après un traitement à l'EGF et dépend de la dose administrée. Aux doses de 100 et $200 \mu \mathrm{g} / \mathrm{kg}$ de poids vif, cette durée a été diminuée de 50 p. 100 par rapport au lot témoin.

Mots clés : Lapin angora, EGF, épilation, poil angora, lapin.

\section{References}

Allen G., Winther M.D., Henwood C.A., Biesley J., Sharry L.F., O'Keefe J., Bennett J.W., Chapman R.E., Hollis D.E., Panaretto B.A., Van Dooren P.H., Edols R.W., Ingl.is A.S., WYNN P.C., Moore G.P.M. (1987). Synthesis and cloning of a gene coding for a fusion protein containing mouse epidermal growth factor. Isolation from transformed $E$. coli and some physical, chemical and biological characteristics of the growth factor. J. Biotechnol. (In press.).

COHEN S., Elliotr G.A. (1963). The stimulation of epidermal keratinization by a protein isolated from the submaxillary gland of the mouse. J. Invest. Dermatol., 40, 1-5.

Green M.R., Basketter D.A., Couchman J.R., Rees D.A. (1983) . Distribution and number of epidermal growth factor receptors in skin is related to epithelial growth. Dev. Biol., 100, 506512.

GREGORY H. (1975). Isolation and structure of urogastrone and its relationship to epidermal growth factor. Nature, 257, 325-327.

Hollenberg M.D., Cuatrecasas P. (1973). Epidermal growth factor : receptors in human fibroblasts and modulation of action by cholera toxin. Proc. Natl. Acad. Sci. U.S.A., 70, 29642968.

Hollis D.E., Chapman R.E., Panaretro B.A., Moore G.P.M. (1983). Morphological changes in the skin and wool fibres of Merino sheep infused with mouse epidermal growth factor. Aust. J. Biol. Sci., 36, 419-434.

Levi-Montalcini R., Cohen S. (1960). Effects of the extract of the mouse submaxillary salivary glands on the sympathetic system of mammals. Annals N.Y. Acad. Sci.. 85, 324-341.

Mattner P.E., Brown B.W., Panaretto B.A. (1985). Sexual activity and seminal characteristics in rams treated with epidermal growth factor. Proc. Aust. Soc. Reprod. Biol., p. 40.

Moore G.P.M., Panaretro B.A., Carter N.B. (1985). Epidermal hyperplasia and wool follicle regression in sheep infused with epidermal growth factor. J. Invest. Dermatol., 84, 172-175.

Moore G.P.M., Panaretto B.A., Robertson D. (1981 a). Effects of epidermal growth factor on hair growth in the mouse. J. Endocrinol, 88, 293-300.

Moore G.P.M., Panaretto B.A., Robertson D. (1981 b). Epidermal growth factor causes shedding of the fleece of Merino sheep. Search, 12, 128-129.

Moore G.P.M., Panaretto B.A., Robertson D. (1982 a). Inhibition of wool growth in Merino sheep following administration of mouse epidermal growth factor and a derivative. Aust. $J$. Biol. Sci., 35, 163-172. 
Muori: G.P.M., Panaretio B.A., Robertson D. (1982 b). Inhibition of wool growth in Merino sheep by epidermal growth factor: production of breaks in the fleece. Wool Harvesting Research and Development. Ed. P.R.W. Hudson. Sydney, Australian Wool Corporation, pp. $57-65$.

Moori: G.P.M., Panaretto B.A., Robertson D. (1983). Epidermal growth factor delays the development of the epidermis and hair follicles of mice during growth of the first coat. Anat. Rec., 205, 47-55.

Moorl: G.P.M., Panaretto B.A., Wallace A.L.C. (1984). Treatment of ewes at different stages of pregnancy with epidermal growth factor : effects on wool growth and plasma concentrations of growth hormone, prolactin, placental lactogen and thyroxine and on foctal development. Acta Endocrinol., 105, 558-566.

Nanney L.B., Magid M., Stroscheck C.M., King L.E. (1984). Comparison of epidermal growth factor binding and receptor distribution in normal human epidermis and epidermal appendages. J. Invest. Dermatol., 83, 385-393.

Panaretto B.A., Moore G.P.M., Robertson D.M. (1982). Plasma concentrations and urinary excretion of mouse epidermal growth factor associated with the inhibition of food consumption and of wool growth in Merino wethers. J. Endocrinol., 94, 191-202.

Radford H.M., Avineli J.A., Panaretto B.A. (1987). Some effects of epidermal growth factor on reproductive function in Merino sheep. $J$. Reprod. Fert. (In press).

Roucizot J., Thébauit R.-G. (1970). Utilisation de la cyclophosphamide comme substance dépilatoire pour la récolte des poils du lapin angora. Ann. Zootech., 19, 229-234.

Rougeot J., Thébault R.-G. (1984). Le lapin angora, sa toison, son élevage. Les Editions du Point Vétérinaire. Maisons-Alfort, $182 \mathrm{pp}$

Savacie C.R. and Conen S. (1972). Epidermal growth factor and a new derivative. J. Biol. Chem., 247, 7609-7611.

Savage C.R., Hash J.H., Cohen S. (1973). Epidermal growth factor location of disulfide bonds. J. Biol. Chem., 248, 7669-7672.

Shaw G., Jorgensen G.I., Tweedali: R., Tinnison M., Waters M.J. (1985). Effect of epidermal growth factor on reproductive function of ewes. J. Endocrinol., 107, 429-436.

Simpson R.J., Smiti J.A., Moritz R.L., O Hari M.J., Rudiand P.S., Morrison J.R., Llovd C.J., Grego B., Burgess A.W., Nicl: E.C. (1985). Rat epidermal growth factor : complete amino acid sequence. Eur. $J$. Biochem., 153, 629-637.

Thébault R.-G., Rougeot J. (1983). Le lapin angora. Revue avicole, 93, 355-367. 